\title{
Sustainable Line of Cotton Wet Processing
}

\section{Dalia F. Ibrahim*}

Faculty of applied arts, Helwan University, Cairo, Egypt

Enzymes have been used for more than 50 years in the detergent, textile, food industries, to name just a few. In these industries enzymes replace chemicals and minimize water, raw material and energy consumption. Natures own technology provides us with environmentally friendly solutions and better products. Enzymes are the natural solution to industrial problems. With enzymes we can maintain the living standards we have today and at the same time preserve the environment for our children. In textile industry, enzymes are used because: they are accelerating the reactions, act only on specific substrates, operate under mild conditions, are safe and easy to control, can replace harsh chemicals and are biologically degradable [1]. In textile manufacturing the use of enzymes has a long tradition. The enzymatic desizing of cotton with $\alpha$-amylases is state-of-the-art since many decades'. Moreover, cellulases, pectinases, hemicellulases, lipases and catalases are used in different cotton pre-treatment and finishing processes [2].

These studies will overview the whole clean line of cotton fabrics wet processing arrangement avoiding usage of chemicals and substituting it with enzymes.

\section{Singing}

Cellulase enzymes are sometimes used on cotton fabrics during wet processing which removes loose fibers as biological singing [3]. This results in increasing wettability, better dyeing characteristics, improving reflection, no "frosty" appearance, a smoother surface, better clarity in printing, improving visibility of the fabric structure, less pilling and decreasing contamination through removal of fluff and lint [4].

\section{Desizing}

Enzyme desizing is the most widely practiced method of desizing starch. For desizing starch, amylase and maltase are used. Amylases enzymes hydrolyse and reduce the molecular weight of amylose and amylopectin in starch, resulting in increasing of its water solubility, hence easier removal from the fabric. Effective enzymatic desizing needs control of $\mathrm{pH}$, temperature, water hardness, electrolyte addition and choice of surfactant [5].

\section{Scouring}

Enzymatic scouring with cellulases and pectinases can be a very effective part of preparing cotton fabrics. The conventional scouring process has been replaced with environment friendly approach using different enzymes. These enzymes remove all non-cellulosic impurities present in the fabric. Such this enzymatic process would enhance the absorbency of the fabric without appreciable strength loss. Also it was found that the water absorbency of the bioscoured fabric was found to be considerably higher than that of the conventionally scoured fabric [6]. On the other hand a potential new biotechnology for improving water absorbency of cotton fibers in textile processing based on the use of cutinase enzyme [7]. Also the bio scouring of cotton was significantly improved using combinations of alkaline pectinase and neutral cellulose/alkaline protease/alkaline xylanase in comparison with individual enzymes [8]. Another mixture of enzymes for scouring of cotton fabrics has been applied using mixture of commercial cellulase, hemicellulose, pectinase and xylanase enzymes [9].

\section{Bleaching}

The bleaching of textile fibers with hydrogen peroxide is certainly the most popular process today. The traditional method of removing the residual hydrogen peroxide is by rinsing the fabric a number of times with water. Alternatively, a mild reducing agent can be used to neutralize the bleach. In either case, large amounts of water (up to 40 liters per $\mathrm{kg}$ of fabric) are required for rinsing the fabric to remove residual hydrogen peroxide. The presence of hydrogen peroxide in the dye bath can cause decolorization of reactive dyes, which are sensitive to oxidization [1]. These rinsing steps were canceled when using enzymes because the bleaching agent is decomposed and the residues of the enzyme have no effect on textile fibers tensile strength or dyestuffs. A catalase enzyme used for bleach cleanup in the textile industry ensures complete removal of excess $\mathrm{H}_{2} \mathrm{O}_{2}$ combined with the reactive dyeing bath in many times after optimize the conditions $[10,11]$.

Besides all these uses of enzymes there are some trials combined two or three procedures of cotton treatments using enzymes, such as:

- Combining of pectinase enzyme (scouring) and peracitic acid (bleaching) in one bath [12].

- Combining of enzymatically desized scoured and bleached of cotton fabrics with an enzyme mixture of starch degrading enzymes, pectinases and glucose oxidases, respectively. Starchdegrading enzymes hydrolyzed the sizing agent into glucose. Glucose oxidases catalyzed the oxidation of $\beta$-D-glucose to $\mathrm{D}$-glucono- $\omega$-lactone and simultaneously generated hydrogen peroxide. For bleaching, hydrogen peroxide was converted into peracetic acid by incorporating the bleach activator Tetra Acetyl Ethylene Diamine (TAED). Bleaching took place at $50^{\circ} \mathrm{C}$ and neutral $\mathrm{pH}$, where peracetic acid is most effective. Pectinases were added into the pre-treatment bath to remove pectins from fibers and improve their wettability [13-18].

- Combining lipase with pectinase in a one-step process enabled to reduce the time required for bioscouring and forming fabrics with superior properties and excellent dyeing performance $[19,20]$.

${ }^{*}$ Corresponding author: Dr. Dalia F. Ibrahim, Faculty of applied arts, Helwan University, Cairo, Egypt, E-mail: drdaliafekry@hotmail.com

Received November 21, 2012; Accepted November 27, 2012; Published December 05, 2012

Citation: Ibrahim DF (2013) Sustainable Line of Cotton Wet Processing. J Textile Sci Eng 3: e114. doi:10.4172/2165-8064.1000e114

Copyright: (c) 2013 Ibrahim DF. This is an open-access article distributed under the terms of the Creative Commons Attribution License, which permits unrestricted use, distribution, and reproduction in any medium, provided the original author and source are credited. 
- Introducing ultrasonic energy during enzymatic treatment of cotton fabric significantly improves enzyme efficiency without affecting the strength of the fabric [21].

- A mixture of enzymes is used, consisting of a temperature stable a-amylase and a pectatelyase, both operating under alkaline conditions. A fast integrated enzyme-based pretreatment process concept for cotton containing textiles has been developed for operation in the continuous mode [22] (Figure $1)$.

\section{Dyeing and Printing}

1- Using of enzymes (lipase-protease-amylase-diastrease) in pretreatment of cotton fabrics combined with tannic acid improve dyeing with natural dyes without using any metallic mordents [23].

2- If a cellulosic fabric is pretreated with enzymes prior to dyeing with direct, reactive or vat dyes, significantly deeper color shades usually result. Cotton fabrics with pre-enzyme treatment had better wrinkle recovery than fabrics with postenzyme treatment. Mechanical agitation of the fabric during enzyme treatment significantly influences fabric compression, shear, flexibility air permeability, moisture diffusion rate, softness, draping behavior and fabric friction.

3- A hazardous chemical has been replaced with eco-friendly horse radish peroxidase enzyme in textile discharge printing. Enzymatic discharge printing was carried out with a phenol oxidizing enzyme system such that the reactive dye was selectively discharged from the cotton fabric in selected areas, creating a printed surface.

4- Laccase enzyme has been used in discharge printing style of cotton fabrics with different reactive dyes [24].

5- Cotton fabrics were dyed with the natural dyes chlorophyll and carmine after treatment with the enzymes cellulase, $\alpha$-amylase and trypsin, resulted in an increase in pigment uptake in all cases compared with the untreated samples, and did not affect fastness properties.

\section{Finishing}

It is clear from the number of studies carried out concerning acid cellulases and its application on cotton fabrics finishing, that the
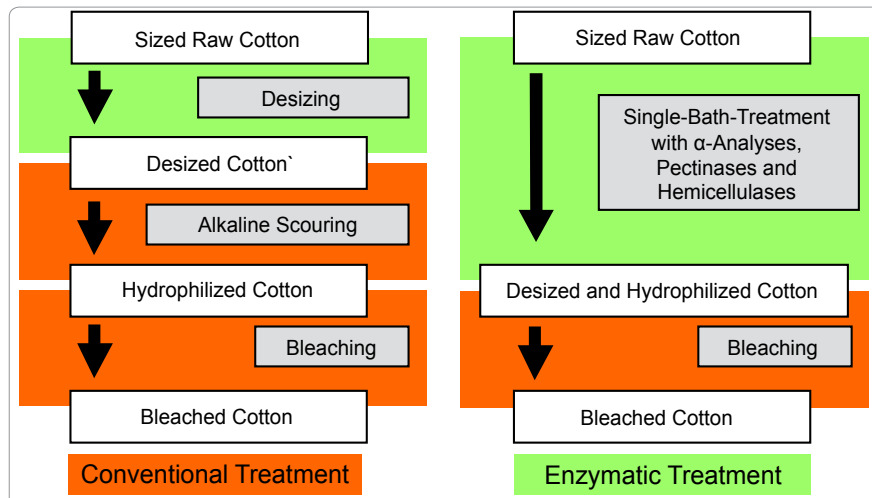

Figure 1: Graphical representation of conventional and enzymatic treatments. use of this enzymes results in a great change in fabric properties. The finishing with some cellulases leads to obtaining of textile surfaces with less pilling and increased gloss. Enzymes make cotton look like silk. Cotton treated with enzymes not only looks better, it also lasts longer. Treating cotton fabrics with unique Biopolishing enzymes removes the small hairs or fuzz that protrude from the surface of the yarn, leaving a smoother yarn surface that almost looks like silk, enhances appearance and handle of the fabrics without compromising on essential properties. Process of bio-polishing is influenced by concentration of cellulases, temperature, $\mathrm{pH}$, and duration of treatment, besides the activity levels of enzymes, method of mechanical agitations and construction features of fabrics. Bio-polishing makes cotton fabrics look brand new, even if you've washed them several times $[23,24]$.

\section{References}

1. Kannan MSS, Nithyanandan R (2008) Enzymatic application for bleach cleanup. The Indian Textile Journal.

2. Gusakov AV, Berlin AG, Popova NN, Okunev, ON, Sinitsyna OA, et al. (2000) A comparative study of different cellulase preparations in the enzymatic treatment of cotton fabrics. Appl Biochem Biotech 88: 119-126.

3. http://en.wikipedia.org/wiki/Pill_\%28textile\%29

4. http://kmdhar.blogspot.in/p/singeing-process.html

5. http://www.ft.tul.cz/depart/ktc/dokumenty/pte/2PTE\%20Desizing.pdf

6. Li Y, Hardin IR (1997) Enzymatic Scouring of Cotton: Effects on Structure and Properties. Text Chem Color 29: 71-75.

7. Degani O, Gepstein S, Dosoretz CG (2002) Potential use of cutinase in enzymatic scouring of cotton fiber cuticle. Appl Biochem Biotech 103: 277-289.

8. Qiang W, Xuerong F, Zhaozhe H, Weidong G, Jian C (2007) Influence of combined enzymatic treatment on one-bath scouring of cotton knitted fabrics. Biocatal Biotransfor 25: 9-15.

9. Csiszar E, Losonczi A, Szakacs G, Rusznak I, Bezur L, et al. (2001) Enzymes and chelating agent in cotton pretreatment. J Biotechnol 89: 271-279.

10. Dyeing in enzyme-treated bleached bath. The Indian Textile Journal.

11. http://www.wisegeek.com/what-is-biopolished-cotton.htm

12. Tavcer FP (2011) Dyeing of Environmentaly Friendly Pretreated Cotton Fabric. Textile Dyeing 78-88.

13. Spicka N, Forte-Tavcer P (2012) Complete enzymatic pre-treatment of cotton fabric with incorporated bleach activator. Text Res J.

14. Karthikeyan K, Dhurai B (2011) New Method of Discharge Printing on Cotton Fabrics Using Horseradish Peroxidase. AUTEX Research Journal 11: 61-65.

15. El-Thalouth IA, Kantouch F, Nassar SH, El-Hennawi HM, Youssef MA (2008) Ecofriendly discharge printing on cotton fabrics using laccase enzyme. Indian J Fibre Text Res 33: 52-57

16. Tsatsaroni E, Liakopoulou-Kyriakides M (1995) Effect of enzymatic treatment on the dyeing of cotton and wool fibres with natural dyes. Dyes Pigments 29 : 203-209.

17. http://www.sigmaaldrich.com/life-science/metabolomics/enzyme-explorer/ learning-center/lysing-enzymes.html

18. Styliani K, Diomi M, Emmanuel K, Dimitris K (2010) Improved Properties of Cotton Fabrics Treated with Lipase and Its Combination with Pectinase. Fibres Text East Eur 18: 86-92.

19. Rajendran R, Sundaram SK, Radhai R, Rajapriya P (2011) Bioscouring of Cotton Fabrics using Pectinase Enzyme its Optimization and Comparison with Conventional Scouring Process. Pakistan Journal of Biological Sciences 14: 519-525.

20. Vankar PS, Shanker R, Verma A (2007) Enzymatic natural dyeing of cotton and silk fabrics without metal mordants. Journal of Cleaner Production 15: 1441 1450 . 
Citation: Ibrahim DF (2013) Sustainable Line of Cotton Wet Processing. J Textile Sci Eng 3: e114. doi:10.4172/2165-8064.1000e114

Page 3 of 3

21. Karaboga C, Korlu AE, Kerim D, Bahtiyari MI (2007) Use of Ultrasonic Technology in Enzymatic Pretreatment Processes of Cotton Fabrics. Fibres Text East Eur 97-100.

22. Lenting HBM, Warmoeskerken MMCG (2004) A fast, continuous enzymebased pretreatment process concept for cotton containing textiles. Biocatal Biotransfor 22: 361-368.
23. Saravanan D, Dinesh C, Karthikeyan S, Vivekanandan A, Nalankilli G, et al. (2009) Biopolishing of cotton fabrics with total cellulases of Trichoderma reese and optimization using Taguchi methods. J Appl Polym Sci 112: 3402-3409.

24. 7th International Conference on Polymer and Textile Biotechnology. Milan Italy. 